\title{
Carcass traits and internal organs of broiler chickens as influenced by coffee weed (Senna occidentalis) leaf ethanolic extract
}

Omoikhoje, S. O., Okooza, M. O., Okeje, R. O. and Peter-Paul, F. E. Department of Animal Science, Ambrose Alli University, P.M.B 14, Ekpoma, Edo State,

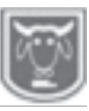

Abstract
Nigeria.

Corresponding author: stanleyoomoikhoje@aauekpoma.edu.ng; soomoikhojeaau@yahoo.com

Carcass traits and internal organs of one hundred and twenty, one day-old broiler chicks maintained on different dosages of coffee weed leaf ethanolic extract for eight weeks were studied. Five dosages (0, 25, 50, 75 and $100 \mathrm{~mL})$ of coffee weed leaf ethanolic extract (CWLEE) per litre of drinking water $\left(T_{1} T_{2}, T_{3}, T_{4}\right.$ and $\left.T_{5}\right)$ were used. The birds were allocated to the various treatment groups in a completely randomized design (CRD) with each treatment replicated three times (8 birds per replicate). Data on carcass traits revealed that live weight (2.50kg/bird), defeathered (2.30kg/bird) and eviscerated (2.00kg/bird) weights as well as dressing percentage (81.69\%) were significantly $(P<0.5)$ higher among birds on $50 \mathrm{~mL}$ of CWLEE compared to those on other treatment groups. Similarly, the relative weights of drumstick (16.60\%) and thigh (22.28\%) were also significantly $(P<0.05)$ better in broiler chickens administered $50 \mathrm{~mL}$ CWLEE. Relative organ weights of broiler showed that weight of heart, lungs, gizzard, bursa, spleen and kidney were significantly $(P<0.05)$ influenced by the treatments. It is therefore inferred that birds administered $50 \mathrm{~mL} C W L E E$ gave better carcass quality and functioning of the vital organs and therefore can be recommended for broiler chickens.

Keywords: Broilers, carcass, coffee weed, extract, organs

\section{Introduction}

In order to achieve maximum health, better growth performance and high carcass weight in poultry birds, nutritionally balanced diet with good vaccinations and treatments are imminent. However, the use of antimicrobials had been adjudged to be one of the most successful chemotherapies against disease causing organisms (Guyue et al., 2014) and they have made significant contributions to the prevention, control and treatment of infectious diseases in animals (Forman and Burch, 1947). The presence of antimicrobial resistant, non-pathogenic commensal bacterial in farms are considered a problem, as it provides a pool of transferable resistance genes (De Francesco et al., 2004). Besides, there is the problem of residual effects of drugs on animal products as well as high cost of the drugs and coverage area. However, available evidence indicated that indigenous health practices including medicinal plants are still being used to handle animal health problems in all livestock production systems (MaedaMachangu et al., 1997, Minja, 1999). Since drugs and antibiotics are used in poultry feed to maximize the efficiency of production, product quality and control of diseases, plants and plant extracts from herbs and spices which are known to have medicinal properties can be used as alternatives to control diseases and improve feed efficiency. This is because they are known to contain bioactive compounds like tannins, saponins, alkaloids etc. that have inhibitory activities against disease causing organisms. Plant derived natural products represent an attractive source of antimicrobial agents since they are natural, 
have manageable side effects and are available at affordable prices. Many of these plants extracts have also been used as feed additives and have been proven to improve gut integrity of monogastric animals. Consequently, plants and extracts from herbs and spices which are known to have medicinal properties are of paramount importance as alternatives for these purposes. One of such plants is coffee weed or septic weed (Senna occidentalis) which had been used as a natural medicinal plant in the rain forest and other tropical areas for decades. Its roots, leaves, flowers and seeds have been employed in herbal medicine around the world (Sambasivam et al., 2016). It has been suggested that Senna occidentalis has the potential for the treatment of allergic and inflammatory diseases and that the various parts of plant are used in livestock production (Sreejith et al., 2010). In previous studies, there was reduction of weight and delay of body growth among birds when the external seed tegument of Senna occidentalis was added to broiler chicken feed (Haraguchi et al., 1998). However, Omoikhoje et al. (2018) observed no detrimental effect on the growth performance, carcass traits and internal organ of broiler chickens when different dosages of Senna occidentalis leaf aqueous extract were added to their drinking water. This study was therefore aimed at evaluating the effect of Senna occidentalis leaf ethanolic extract on the carcass traits and organ weights of broiler chickens.

\section{Materials and methods \\ Experimental location and duration}

The experiment was carried out at the Poultry Unit of the Livestock Teaching and Research Farm, Ambrose Alli University, Ekpoma for eight (8) weeks.

Sources of ingredients and fresh coffee weed leaves

The ingredients for the broiler starter and finisher diets were purchased from a reputable feed dealer in Benin City, Edo State, Nigeria. Fresh coffee weed (Senna occidentalis) leaves were purchased from Ekpoma main market in Esan West Local Government Area, Edo State, Nigeria.

\section{Processing of coffee weed leaves}

The fresh leaves were thoroughly rinsed and sparsely spread on jute mat at room temperature for $6-7$ days until they became crispy. The leaves were turned regularly to avoid uneven drying and decay to ensure that the greenish colour of the leaves was maintained. The dried crispy leaves were hammer milled and passed through a $2 \mathrm{~mm}$ sieve and stored in an air tight plastic container to avoid the absorption of moisture till they were used for laboratory analysis and preparation of the ethanolic extract. A measured quantity $(100 \mathrm{~g})$ of the ground leaves was infused in $400 \mathrm{ml}$ of ethanol overnight (12hours). Thereafter, the solution was filtered through a fibre sieve clothe. The filtrate was concentrated to dry form using a water bath at $60^{\circ} \mathrm{C}$. A measured quantity $(1.36 \mathrm{~g})$ of the filtrate was mixed in 1litre of water to serve as standard concentration, from which a measured quantity of the concentrate according to the experimental treatment was added to 1litre of drinking water and served to the birds ad-libitum.

\section{Feeding and experimental treatments}

The birds were fed commercial diet for one (1) week acclimatization period after which they were fed formulated starter and finisher diets (Table1). In addition, five (5) treatments $\left(\mathrm{T}_{1}, \mathrm{~T}_{2}, \mathrm{~T}_{3}, \mathrm{~T}_{4}\right.$ and $\left.\mathrm{T}_{5}\right)$ were prepared to contain $0,25,50,75$ and $100 \mathrm{~mL}$ of coffee weed leaf ethanolic extract (CWLEE) per litre of drinking water, while $2.5 \mathrm{~g}$ of synthetic antibiotic (Tyloxin, $100 \mathrm{~g} / \mathrm{mL}$ ) was served to the birds as positive control $\left(\mathrm{T}_{1}\right)$ on a weekly interval. 
Table 1: Nutrient composition of the formulated starter and finisher diets

\begin{tabular}{lll}
\hline Nutrient Composition \% & Starter & Finisher \\
\hline Maize & 53.00 & 55.00 \\
Soya bean meal & 30.00 & 23.00 \\
Fish meal & 1.50 & 1.50 \\
Palm kernel cake & 5.60 & 8.00 \\
Wheat offal & 5.60 & 8.20 \\
Bone meal & 2.50 & 2.50 \\
Limestone & 1.00 & 1.00 \\
Premix & 0.30 & 0.30 \\
Lysine & 0.10 & 0.10 \\
Methionine & 0.10 & 0.10 \\
Salt & 0.30 & 0.30 \\
\hline Total & 100.00 & 100.00 \\
Calculated Analyses & & \\
Crude Protein & 21.22 & 19.11 \\
Metabolizable Energy $(\mathrm{Kcal} / \mathrm{kg})$ & 2809.39 & 2805.93 \\
\hline
\end{tabular}

Experimental birds, design and management

A total of 120 broiler chicks were used for the experiment. Twenty-four (24) chicks were randomly selected and allocated to each of the five (5) treatment groups $\left(\mathrm{T}_{1}, \mathrm{~T}_{2}\right.$, $\mathrm{T}_{3}, \mathrm{~T}_{4}$ and $\mathrm{T}_{5}$ ) in a completely randomized design (CRD). Each treatment group contained three (3) replicates with eight (8) birds per replicate. The chicks were brooded for four (4) weeks during which they were fed a commercial starter diet for one week acclimatization period. Thereafter, the coffee weed leaf ethanolic extract (CWLEE) at different dosages of 0 , $25,50,75$ and $100 \mathrm{~mL}$ was added to their drinking water as $\mathrm{T}_{1}, \mathrm{~T}_{2}, \mathrm{~T}_{3}, \mathrm{~T}_{4}$ and $\mathrm{T}_{5}$ respectively. The birds were allowed free access to the diets and treatments ad libitum throughout the duration of the study. All routine management practices were carried out including vaccination.

\section{Carcass traits and relative organ weights studies}

At the end of the eight weeks feeding trial, all birds were fasted overnight and two (2) chickens were randomly selected from each replicate making a total of six (6) chickens per treatment group, tagged and their live weights taken. The slaughtered birds were dipped in hot water for about one (1) minute and the feathers were plucked and weighed to get the plucked weights. The plucked chickens were eviscerated and weighed as eviscerated weights. The dressing percentage was expressed as the percentage ratio of the eviscerated weight to live weight. Thereafter, the carcass was cut into parts (drumstick, breast, thighs, wings, shanks, neck, back and head), while the viscera organs (liver, heart, lungs, gizzard, bursa, spleen and kidney) were excised, blotted free of blood and weighed. The weight of each of the cut parts and organs were expressed relative to the eviscerated weight of the birds.

\section{Statistical analysis}

Data generated were subjected to a one-way analysis of variance (ANOVA) and treatment means that significantly differed were compared using the Duncan's Multiple Range Test (DMRT) as outlined by Steel and Torrie (1990) using the SPSS (2014) IBM version 20.

\section{Results and discussion}

The data on carcass characteristics as influenced by coffee weed ethanolic leaf extract (Table 2) indicated that live weight, defeathered weight, eviscerated weight, dressing percentage, drumstick and thigh weights were significantly affected by the treatments. While the relative weights of breast, wings, shank, neck, back and head 
were not affected by the treatments. The higher live weight observed in birds on $50 \mathrm{~mL}$ of coffee weed leaf ethanolic extract (CWLEE) compared to other treatments which translated to higher defeathered and eviscerated weights could be due to available protein and metabolizable energy, mineral and low anti-nutrient substances (Oloruntola et al., 2016). The dressing percentage obtained in this study was within the range of $77.00-82.30 \%$. The highest value $(82.30 \%)$ was obtained in birds given 0mL CWLEE (control) but compared favourably with 81.82 and $81.69 \%$ recorded in broiler chickens that had 25 and $50 \mathrm{~mL}$ CWLEE respectively. However, these values were higher than the range of $60.30-$ $74.65 \%$ (Bamgbose et al., 1999) but fell within the range of $77.33-83.00 \%$ (Akpodiete et al., 1997) and lower than 79.84 - 86.96\% (Omoikhoje et al., 2018). Relative weight of drumstick and thigh of birds on $50 \mathrm{~mL}$ CWLEE was better than those on other treatments, while thigh and breast were not different amongst the treatment groups. In the same vein, the relative weight of thigh was better for chickens served 50mL CWLEE, although did not differ from those of treatments 1,2 and 5. The relative weight of wings, shank, neck, back and head were not significantly $(\mathrm{P}>0.05)$ influenced by the treatments and this supported the position of Tarek et al.
(2013) but disagreed with Nworgu et al. (2007). The improved relative weight of drumstick, thigh and breast for birds that had the CWLEE based treatments may be because of the better feed conversion ratio which accumulated into more muscle meat in the birds. This observation is in line with the report of Ghazalah and Ali (2008); that the use of herbs and its products in livestock feed and water to stimulate effective use of feed nutrient may result in more efficiency. This is because leaves contain active substances that can improve digestion and metabolism and possess bacterial and immunostimulant activities. In the light of this, Sultan et al. (2015) reported that the use of Azadirachta indica leaf extracts in broiler chicken production exhibited better nutrient digestibility of crude protein and ether extract coupled with improved intestinal histomorphology. This therefore suggests that coffee weed leaf ethanolic extract increased the ability of the birds to utilize available nutrients in the feed and the extract. Therefore, it can be alluded that better profit margin will be achieved for birds maintained on these treatments $(2,3,4$ and 5) because these cut parts are the valuable and highly priced cut parts. Consequently, it can be inferred that broiler chicken served 50mL CWLEE had a better carcass quality compared to other treatments.

Table 2: Carcass traits of broiler chickens as affected by the experimental treatments

\begin{tabular}{|c|c|c|c|c|c|c|}
\hline \multirow{4}{*}{ Parameters } & \multicolumn{5}{|c|}{ Experimental treatment $(\mathrm{T})$} & \multirow[b]{4}{*}{ SEM \pm} \\
\hline & 1 & 2 & 3 & 4 & 5 & \\
\hline & \multicolumn{5}{|c|}{ Dosages of CWLEE (mL) } & \\
\hline & 0 & $25^{\circ}$ & $\mathbf{5 0}$ & 75 & 100 & \\
\hline Live weight (kg/bird) & $2.07^{b}$ & $2.20^{\mathrm{b}}$ & $2.50^{\mathrm{a}}$ & $2.17^{\mathrm{b}}$ & $2.03^{\mathrm{b}}$ & 0.04 \\
\hline Defeathered weight (kg/bird) & $1.90^{\mathrm{b}}$ & $2.00^{\mathrm{b}}$ & $2.30^{\mathrm{a}}$ & $2.03^{\mathrm{b}}$ & $1.93^{\mathrm{b}}$ & 0.05 \\
\hline Eviscerated weight (kg/bird) & $1.70^{\mathrm{b}}$ & $1.80^{\mathrm{b}}$ & $2.00^{\mathrm{a}}$ & $1.77^{\mathrm{b}}$ & $1.57^{\mathrm{c}}$ & 0.03 \\
\hline Dressing percentage $(\%)$ & $82.30^{\mathrm{a}}$ & $81.82^{\mathrm{a}}$ & $81.69^{\mathrm{a}}$ & $80.00^{\mathrm{b}}$ & $77.00^{\mathrm{c}}$ & 0.36 \\
\hline \multicolumn{7}{|l|}{ Cut Parts (\%) } \\
\hline Drumstick & $15.21^{\mathrm{b}}$ & $15.28^{\mathrm{b}}$ & $16.60^{\mathrm{a}}$ & $14.51^{\mathrm{c}}$ & $13.62^{\mathrm{d}}$ & 0.11 \\
\hline Breast & 17.11 & 18.02 & 20.37 & 18.54 & 18.08 & 1.12 \\
\hline Thighs & $19.80^{\mathrm{ab}}$ & $19.24^{\mathrm{b}}$ & $22.28^{\mathrm{a}}$ & $17.93^{\mathrm{b}}$ & $21.14^{\mathrm{ab}}$ & 0.70 \\
\hline Wings & 16.96 & 16.84 & 16.72 & 17.90 & 16.42 & 0.75 \\
\hline Shank & 6.76 & 6.45 & 8.64 & 6.11 & 6.56 & 0.45 \\
\hline Neck & 6.53 & 6.66 & 8.19 & 7.13 & 6.40 & 0.36 \\
\hline Back & 7.13 & 7.48 & 9.03 & 7.68 & 7.52 & 0.35 \\
\hline Head & 3.45 & 3.30 & 3.54 & 2.37 & 3.54 & 0.08 \\
\hline
\end{tabular}




\section{Omoikhoje, Okooza, Okeje and Peter-Paul}

The relative organ weights of broiler chickens (Table 3) showed that relative weights of liver were not significantly $(\mathrm{P}>0.05)$ influenced by the treatments, whereas, the relative weights of heart, lungs, gizzard, bursa, spleen and kidney were significantly $(\mathrm{P}<0.05)$ different amongst the treatment groups. This point to the fact that CWLEE did not cause any toxicity and abnormal metabolic activity in the organs or system of the birds as observed by Omoikhoje et al. (2018) when broiler chickens were administered coffee weed leaf aqueous extract. The relative weight of liver did not vary among birds on the entire treatment group and this may be ascribed to the quality of the test diets. This however negates the report of Omoikhoje et al. (2018) who observed significant variations in the relative weights of the liver of birds placed on coffee weed leaf aqueous extract. The relative weight of heart of birds placed on $75 \mathrm{~mL}$ inclusion level of CWLEE was higher statistically but not different from the control and treatments 3 and 4. The lungs weight of birds placed on the control had higher value and differed from all other treatments but similar to those on treatments 3, 4 and 5. The weights of gizzards, bursa and spleen were higher in birds on $75 \mathrm{~mL}$ CWLEE compared to other treatments but for gizzard weight, the values in treatments 1, 2 and 5 were not different from another. Similarly, the values of bursa and spleen in treatments 1, 2, 4, 5 and 1, 2, 3 and 5 respectively were not different from one another. The relative weight of kidney was markedly higher in $100 \mathrm{~mL}$ CWLEE compared to other treatments. However, the increased weight of the gizzard at $75 \mathrm{~mL}$ dosage of CWLEE may be due to the high fibre content of the extract because increase in high fibre intake could lead to increase in gizzard weight. Besides, gizzard weight must increase due to increased activity of the organ to blend feed (Aderolu et al., 2007). This observation agreed with the findings of Edache et al. (2017) on significant variation in the gizzard weights of colouring quails fed varying level of bakery whole meal. Furthermore, the nonsignificant variation in the values of the relative weights of the liver and the comparable values of the weights of the kidney in birds that had 25 and $50 \mathrm{~mL}$ CWLEE to that in the control points to the fact that CWLEE did not illicit any toxic response. This is because these organs are keys to detoxification and did not undergo any hypertrophy (Tarimbuka et al., 2017; Omoikhoje et al., 2018)

Table 3: Relative organ weight of broiler chickens as affected by experimental treatments

\begin{tabular}{|c|c|c|c|c|c|c|}
\hline \multirow[b]{4}{*}{ Organs (\%) } & \multicolumn{5}{|c|}{ Experimental treatment $(\mathrm{T})$} & \multirow[b]{4}{*}{ SEM \pm} \\
\hline & \multirow[t]{2}{*}{1} & 2 & 3 & 4 & 5 & \\
\hline & & \multicolumn{3}{|c|}{ Dosages of CWLEE (ml) } & \multirow[b]{2}{*}{100} & \\
\hline & $\mathbf{0}$ & 25 & 50 & 75 & & \\
\hline Liver & 2.42 & 2.46 & 2.70 & 2.93 & 2.96 & 0.10 \\
\hline Heart & $0.78^{\mathrm{ab}}$ & $0.67^{b}$ & $0.71^{\mathrm{ab}}$ & $0.85^{\mathrm{a}}$ & $0.76^{\mathrm{ab}}$ & 0.03 \\
\hline Lungs & $0.94^{\mathrm{a}}$ & $0.59^{\mathrm{b}}$ & $0.81^{\mathrm{ab}}$ & $0.70^{\mathrm{ab}}$ & $0.63^{\mathrm{ab}}$ & 0.03 \\
\hline Gizzard & $3.02^{\mathrm{ab}}$ & $2.85^{\mathrm{ab}}$ & $2.49^{\mathrm{b}}$ & $3.61^{\mathrm{a}}$ & $3.21^{\mathrm{ab}}$ & 0.16 \\
\hline Bursa & $0.81^{\mathrm{b}}$ & $0.89^{\mathrm{b}}$ & $0.88^{\mathrm{b}}$ & $1.43^{\mathrm{a}}$ & $1.42^{\mathrm{a}}$ & 0.03 \\
\hline Spleen & $0.11^{\mathrm{b}}$ & $0.10^{\mathrm{b}}$ & $0.13^{\mathrm{ab}}$ & $0.17^{\mathrm{a}}$ & $0.13^{\mathrm{ab}}$ & 0.01 \\
\hline Kidney & $0.19^{c}$ & 0.22 & $0.25^{\mathrm{bc}}$ & $0.37^{\mathrm{a}}$ & $0.55^{\mathrm{a}}$ & 0.03 \\
\hline
\end{tabular}

abc: Means in the same row with varying super scripts differ significantly $(\mathrm{P}<0.05)$ 
Carcass traits and internal organs of broiler chickens as influenced by coffee weed (Senna occidentalis) leaf ethanolic extract

\section{Conclusion}

The inclusion of CWLEE at $50 \mathrm{~mL}$ level in drinking water generally improved the carcass quality and normal functioning of the organs in broiler chickens. Therefore, $50 \mathrm{~mL}$ of coffee weed leaf ethanolic extract can safely be used without any adverse effect on carcass quality and internal organ of broiler chickens.

\section{References}

Aderolu, A. Z. Iyayi, F. A. and Onilude, A. A. 2007. Performance, organ relative weight, serum and haematology parameters in broiler dried grain. Pakistan J. of Nutr. 6(3): 204-208.

Akpodiete, O. J., Ologboho, A. D. and Ayoade, O. G. 1997. Replacement value of maggot meal for fish meal in broiler chicken diets. Proceedings of the $2^{\text {nd }}$ Annual Conference of Animal Science Association of Nigeria.

Bamgbose, A. M., Oyewoye, E. O., Apata, H. O., Mohammed, A. S. and Musa, A. M. 1999. Utilization of roasted full-fat soya bean in diets for broiler chickens. Proceedings of the 24thvAnnual Conference of the Nigerian Society for Animal Production.(NSAP) Pp. 176-177.

DeFrancesco, K.A., Cobbold, R. N., Rice, D. H., BEsser, T. E. and Hancock, D. D. 2004. Antimicrobial resistance of commensal Escherichia coli from dairy cattle associated with recent multi resistance salmonella outbreaks. Vet. Microbiol. 98: 55-61.

Edache, J. A., Tulean, C. D., Muduudtai, R. U. and Yisa, A. G. 2017. Effects of feeding varying levels of bakery waste meal on the performance and carcass values of growing coturnix quails (Cortunix cortunix japonia).
Nig. J. Anim. Prod. 44(3): 294 299

Forman, C. R. and Burch, J. E. 1947. Use of sodium sulphonamides as single injection specific treatment in foot rot. J. of American Vet. Med. Assoc.. 111:208-214

Ghazalah, A. A. and Ali A. M. 2008. Rosemary leaves as dietary supplement for growth in broilers. Inter. J. of Poult. Sci.7(3): 234 239.

Guyue, C. Hafiz, I. H. Haihong, H., Lingli, H., Menghona, D., Xiaohui, A., Yuloan, W. Zahid, I., Zheli, L. and Zonghui, Y. 2014. Benefits and risk of antimicrobial use in food producing animals. Frontiers in Microbio 5, article 288

Haraguchi, M., Gorniak, S. L., Calore, E. E., Cavaliere, M. J., Raspantini, P. C., Calore N. M. P. and Dagli M. 1998. Muscle degeneration in chicks caused by Senna occidentalis seeds. Avian Path. 27: 346-351.

Maeda-Machangu, A. D., Mutayoba, S. K., Laswai, G. H., Kurcoisita, R. V., Kimamboi, S. K., Kondela, A. and Kassy, H. 1997. Local knowledge in animal health in different livestock production systems in Tanzania. TVA J. 16: $230-255$.

Minja, M. M. J. 1999. The maasai wonder plants: a paper presented at people and plants workshop held in Arusha at TPRI 15-18 March.

Nworgu, F. C., Ogungbenro, S. A. and Sloes, K. S. 2007. Performance and some blood chemistry indices of broiler chickens served fluted pumpkin (Telfaria occidentalis) leaves extract supplemented. American Euraisan J. of Agric. and Environ. Sci. 2(1): 90 - 98. 
loruntola, O. D., Ayodele, S. O., Adeyeye, S. A. and Ogunsipe, M. H. 2016. Proximate, mineral and antinutrients composition of Alchornea cordfolia leaf meal. Proceedings of the $21^{\text {st }}$ Annual Conference of Animal Science Association of Nigeria. Pp 18-22

moikhoje, S. O. Obasoyo, D. O., Okosun, S. E., Uwaya, J. I., Adamu, I. and Idahor, E. 2018. Impact of coffee weed (Senna occidentalis) leaf aqueous extract as probiotic on the performance of broiler chickens in humid tropical environment. Microbio. Res. J. Inter. 23(6): 1 10. Article no. MRJI 40971

Sambasivam, M., Vellingiri, V. and Pemaiah, J. 2016. Chemical nutritional properties of aerial parts of Cassia occidentalis (L). J.of Food and Drug Anal. 24: 508 -515 .

SPSS. 2014. Statistical Package for Social Sciences.Version 2.0 model of IBMSS.

Sreejith, G., Latha, P. G., Shine, V. J., Anuja, G. I., Suja, S. R, Sini, S., Shyama, S., Predeep, S., Shikha, P. and Rasasekharan, S. 2010. Anti-allegic, anti-inflammatory and anti-lipid peroxidant effects of Cassia occidentalis (L). India J. Exp. Bio. 5(48): 495 - 498.
Steel, R. G. D. and Torrie, J. H. 1990. Principle and Procedure of statistics. A Biometrical Approach $3^{\text {rd }}$ Edition. MacGraw Hill Book Co. New York.

Sultan, M., Atif, R., Muhammad, Y., Pervez, G., Hulam, A., Khawar, H., Aisha, M. and Muhammad, K. 2015. Comparative efficacy of different herbal plants leaf extract on haematology, intestinal histomorphology and nutrient digestibility in broilers. $A d v$. Zoo and Bot. 3(2): $11-26$

Tarimbuka L. I., Yusuf, H. B., Wafar R. J. 2017. Response of weaner rabbits fed toasted sickle pod (Senna occidentalis) seed meal. Asian J. of Adv. In Agric. Res. 1(1): $1-8$

Tarek, M., Shafey, I. M. and Al-Ruqael, S. I. 2013. Effect of feeding olive extract (Oleuropetin) on the performance, nutrient utilization, small intestine and carcass characteristics of broiler chickens. Vet. Adv. 12(6): 740-746.

Received: $4^{\text {th }}$ August, 2019 Accepted: $18^{\text {th }}$ December, 2019 